\title{
Pemberdayaan Masyarakat Melalui Pengelolaan Sampah Plastik Menjadi Premium dan Solar Alternatif di Desa Buluagung Kecamatan Siliragung Kabupaten Banyuwangi
}

\author{
Nur Anim Jauhariyah', Nurul Inayah ${ }^{2}$, Mahmudah ${ }^{3}$, M. Alaika Nasrulloh ${ }^{4}$ \\ IAI Darussalam Blokagung Banyuwangi \\ Email: ${ }^{1}$ animjauhariyah@gmail.com, ${ }^{2}$ ninailzam2015@gmail.com
}

\begin{abstract}
The type of program of activities in this service is Community Empowerment Through Processing Plastic Waste into Premium and Alternative Solar in Buluagung Village, Siliragung District, Banyuwangi Regency, namely to process plastic waste processed into fuel oil by using a plastic catalyst machine as a village innovation, because the BUMDes "Panji Samudera "Has been facilitated by the village with a machine that can process plastic waste into fuel oil. Conclusions in this empowerment 1) The need to optimize community participation in utilizing plastic waste processing equipment into fuel oil (BBM) in Buluagung Village so that by utilizing plastic waste in addition to reducing plastic waste but also can bring a source of income for the surrounding community. 2) The need for refreshment in the BUMDES organizational structure 'Panji Samudera', due to lack of coordination and synchronization of communication with the community, causing the underutilization of the use of existing plastic catalyst machines.
\end{abstract}

Keywords: Empowerment, Waste, Fuel Oil

\section{Pendahuluan}

Desa Sumberagung adalah salah satu desa di Kabupaten Banyuwangi yang berada di wilayah bagian selatan tepatnya dikaki Gunung Tumpang Pitu, Gunung Lompong, Gunung Bayur, dan Bukit Kapur (Gunung Gamping). Desa Sumberagung memiliki jarak dari pusat pemerintah kabupaten sepanjang $65 \mathrm{~km}$. Secara administratif Desa Sumberagung masuk di wilayah Kecamatan Pesanggaran Kabupaten Banyuwangi.

Berdasarkan data yang telah diperoleh dari survei di lapangan, menunjukkan bahwa dewasa ini terjadi beberapa permasalahan pada masyarakat Desa Buluagung. Permasalahan ini bertumpu pada 
keorganisasian Badan Usaha Milik Desa (BUMDes) "Panji Samudera” yang belum bergerak untuk pemanfaatan inovasi desa berupa mesin katalisator plastik yang mana dengan ini Desa Buluagung menjadi desa percontohan se Banyuwangi. Oleh karena itu, kami berusaha untuk membantu warga dalam mengatasi masalah tersebut, salah satunya dengan pemberdayaan shodaqoh sampah plastik diolah menjadi bahan bakar minyak di Desa Buluagung. Diharapkan dengan adanya pemberdayaan ini dapat menjadi gerakan baru yang menjadi acuan jangka panjang bagi masyarakat Desa Buluagung, sehingga Buluagung menjadi desa bebas sampah plastik serta benar-benar menjadi desa inovasi yang. Pada akhirnya program yang akan kami selenggarakan akan sangat membantu mengurangi sampah plastik serta mampu meningkatkan pendapatan desa guna kesejahteraan masyarakat Desa Buluagung.

Observasi di lapangan menunjukkan bahwa sebagian besar masyarakat Desa Buluagung mengetahui tentang pemanfaatan memasok sampah plastik tersebut hanya saja kurang sadar akan hal tersebut karena tidak ada komando dari yang bersangkutan atau anggota BUMDes. Karena fakta tersebut, maka perlu koordinasi dengan perangkat desa, seluruh kepala dusun, pokja, ketua RT, ketua RW dari tiap dusun di Desa Buluagung bersama-sama mencapai mufakat untuk memecahkan permasalahan tersebut. Sehingga Pemberdayaan Masyarakat Melalui Pengelolaan Sampah Plastik Menjadi Premium dan Solar Alternatif di Desa Buluagung Kecamatan Siliragung Kabupaten Banyuwangi dapat terealisasi dengan optimal.

\section{Metode}

Jenis program kegiatan dalam pengabdian ini adalah Pemberdayaan Masyarakat Melalui Pengolahan Sampah Plastik Menjadi Premium dan Solar 
Alternatif di Desa Buluagung Kecamatan Siliragung Kabupaten Banyuwangi yaitu untuk mengolah sampah plastik diolah menjadi bahan bakar minyak dengan menggunakan mesin katalisator plastik sebagai inovasi desa, karena pihak BUMDes "Panji Samudera" telah difasilitasi oleh desa dengan mesin yang dapat memproses sampah plastik menjadi Bahan Bakar Minyak. Namun kendalanya pihak BUMDes belum maksimal dalam pengelolaannya dikarenakan keperdulian masyarakat sekitar untuk menyetorkan sampah dan memilah sampah plastik masih tergolong kurang perduli sehingga BUMDes sendiri belum mampu menggerakkannya. Dengan alasan permasalahan yang telah dipaparkan di awal pada pohon masalah bahwasannya sulitnya menggerakkan seluruh warga Desa Buluagung dikarenakan peradaban yang kurang dalam lintas agama di garis nasionalis, sehingga menyebabkan missed communication karena munculnya rasa kurang solid antar umat beragama.

Subyek pemberdayaan ini adalah seluruh Kepala Dusun di Desa Buluagung, kelompok Kerja, Ketua RW, Ketua RT dan perangkat Desa Buluagung. Dengan tujuan bermusyawarah bersama sehingga mencapai mufakat. Kemudian kepala dusun mengumpulkan warga dusunnya masingmasing guna mensosialisasikan pemberdayaan shodaqoh sampah plastik yang dipasok di lokasi pengolahan sampah plastik.

Demi terselenggaranya program ini maka perlu membentuk strategi yang tepat sehingga program ini dapat dilaksanakan dengan berkelanjutan. Strategi yang paling efektif yang kami gunakan adalah melibatkan perangkat desa untuk campur tangan dalam kegiatan ini, yaitu dengan mengumpulkan seluruh kepala dusun, ketua RT dan RW serta kelompok kerja dari tiap dusun guna musyawarah dan membangun solidaritas bersama anggota BUMDes "Panji Samudera". Kesepakatan setiap RT diberikan 10 bank sampah khusus sampah plastik sehingga dapat efektif dan terkondisikan. Kemudian bank sampah diambil oleh anggota BUMDES yang bertugas dalam pengambilan 
sampah tersebut. Terakhir, sampah plastik dari setiap dusun, dipasok ke lokasi pengolahan sampah plastik menjadi BBM di rumah Bapak Ihsan Siroj selaku Kertua BUMDes "Panji Samudera”.

Selain itu, membiasakan untuk memungut sampah plastik di setiap kegiatan yang untuk dibawa ke lokasi pengolahan sampah plastik, sebagai percontohan dan membentuk tradisi di Desa Buluagung untuk memungut sampah plastik di kegiatan apapun untuk dishodaqohkan di desa sendiri. Karena pada akhirnya BBM tersebut mampu menjadi pemasukan untuk desa, setelah lulus uji coba dari kabupaten mengenai tingkat keamanan BBM tersebut untuk mesin motor, mobil dan lain sebagainya

Realisasi waktu pelaksanaan program dengan tema Pemberdayaan Mayarakat Melalui Pengolahan Sampah Plastik Menjadi Premium dan Solar Alternatif di Desa Buluagung Kecamatan Siliragung Kabupaten Banyuwangi dilaksanakan pada tanggal 01-30 September 2019 dengan melibatkan mahasiswa untuk melaksanakan pendekatan kepada masyarakat.

Tabel 1. Realisasi Waktu Pelaksanaan Program

\begin{tabular}{|c|c|c|c|}
\hline Nama kegiatan & Minggu & Tempat & Keterangan \\
\hline Pengumpulan Data & \multirow[b]{2}{*}{ Pertama } & Rumah ke. BUMDES & Terealisasi \\
\hline Mengumpulkan sampah plastik & & $\begin{array}{l}\text { Di Setiap Lokasi } \\
\text { Kegiatan }\end{array}$ & Terealisasi \\
\hline $\begin{array}{l}\text { Pemberdayaan shodaqoh } \\
\text { sampah plastik }\end{array}$ & \multirow[t]{2}{*}{ Kedua } & $\begin{array}{ll}\text { Balai } & \text { Desa } \\
\text { Buluagung } & \\
\end{array}$ & Terealisasi \\
\hline Mengumpulkan sampah plastik & & Lokasi Kegiatan & Terealisasi \\
\hline $\begin{array}{l}\text { Merealisasikan shodaqoh } \\
\text { sampah plastik }\end{array}$ & \multirow[t]{2}{*}{ Ketiga } & Lokasi Kegiatan & Terealisasi \\
\hline Mengumpulkan sampah plastik & & Lokasi Kegiatan & Terealisasi \\
\hline Evaluasi program & \multirow[b]{2}{*}{ Keempat } & Lokasi Kegiatan & Terealisasi \\
\hline $\begin{array}{l}\text { Praktik mengolah sampah } \\
\text { plastik menjadi BBM bersama } \\
\text { Dinas Lingkungan Hidup } \\
\text { Kabupaten Banyuwangi }\end{array}$ & & BUMDes & Terealisasi \\
\hline
\end{tabular}

Sumber: Kegiatan Lapangan, 2019 
Langkah awal yang dilakukan oleh tim pengabdian adalah kami mencari tahu sendiri kondisi masyarakat Desa Buluagung melalui staf-staf yang bekerja di Kantor Desa Buluagung, diantaranya Bapak Ipong Dermawan, S.H (selaku kepala Desa Buluagung), bapak Abdul Rahman (selaku sekretaris Desa Buluagung), bapak syamsuri (selaku Kaur Pemerintahan Desa Buluagung) dan beberapa orang staf desa di bidang-bidang lainnya. Selain itu, ternyata dari masyarakat Desa Buluagung ternyata ada juga merupakan salah satu dari alumni Ponpes Darussalam Blokagung sekaligus pengurus Al Adab yaitu bapak Abdur Rahman, dimana beliau bersama keluarga besar tinggal di Desa Buluagung. Adapun pendekatan dan koordinasi untuk merealisasikan pemberdayaan ini dilakukan dengan koordinasi, diantaranya:

\section{Kepala Desa}

Kepala Desa Buluagung, sekdes, dan pihak desa sangat merespon positif kedatangan tim pengabdian. Sekdes juga menjelaskan kondisi Desa Buluagung dan masalah-masalah yang terjadi saat ini sejauh yang diketahuinya.

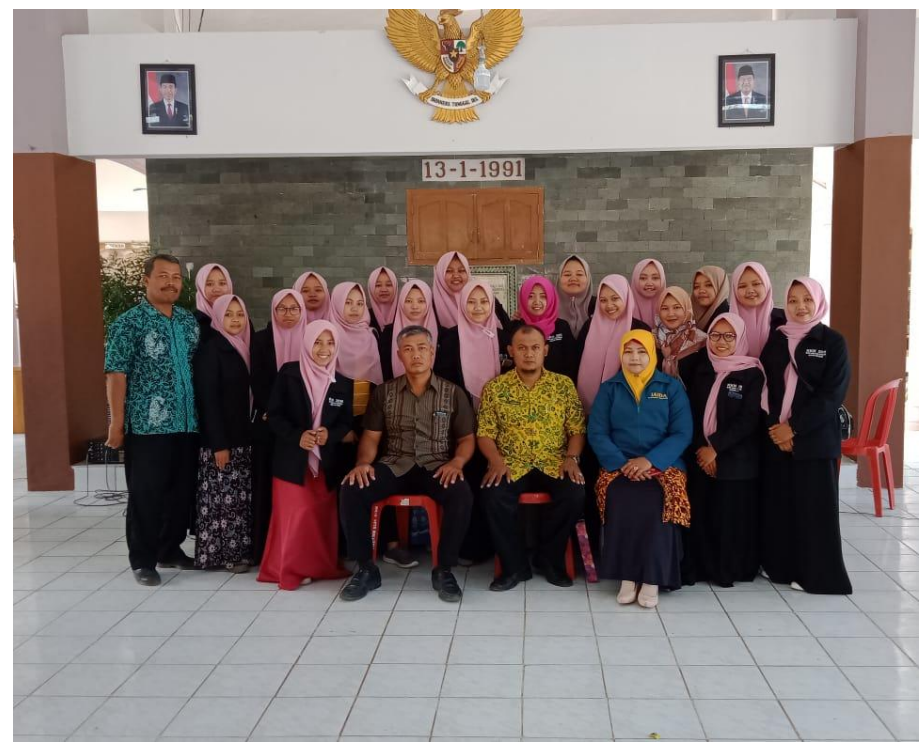

\section{Gambar 1. Koordinasi Tim Dengan Pihak Desa Buluagung}

(Sumber: Dokumentasi, 2019) 


\section{Kepala Dusun}

Ada 4 dusun yang terbentuk di Desa Buluagung ini, yaitu Dusun Krajan, Sidorukun, Pecemengan dan Purwosari. Berdasarkan informasi yang tim peroleh dari fakta di lapangan menunjukkan bahwa ketiga Kadus tersebut merupakan orang-orang yang telah mendapatkan amanah dari warga untuk memimpin di masing-masing dusun tersebut.

3. Tokoh Masyarakat dan Tokoh Agama

Setelah melakukan pertemuan dengan pihak desa dan jajarannya, terutama dengan Bapak kepala Desa Buluagung pada hari sebelumnya sesuai saran dari beliau agar kami mengunjungi sesepuh, tokoh agama, dan tokoh masyarakat yang ada di Desa Buluagung. Salah seorang dari mereka adalah bapak Buhaini, Pak RT, RT dan seorang tokoh agama yakni Pak Rohman Pecemengan. Kami banyak memperkenalkan maksud dan tujuan kami melaksanakan kegiatan pengabdian ini kepada tokoh masyarakat Desa Buluagung, tenyata warga dan tokoh masyarakat merespon positif atas kedatangan kami dan beliau banyak memberikan wejangan serta saran, bahkan kami di berikan sebuah pesan "Jangan sungkan-sungkan berkonsultasi dengan saya maupun warga kami untuk minta saran, pendapat serta segala sesuatu yang dibutuhkan untuk kebaikan dan kemajuan bersama”. Mendengar hal itu, kami menyambut baik dengan mohon dukungan serta partisipasinya beliau serta warga untuk mensukseskan program-program yang akan kami laksanakan di desa ini.

4. Tokoh Pemuda

Selaku tokoh pemuda yang ada di tatanan wilayah pedesaan, yang tentunya sangat berperan dalam kemajuan dan perkembangan desanya sendiri sebagaimana peran tokoh muda sebagai penerus bangsa dan agama melalui lingkup yang lebih kecil yaitu desa. Selain itu, mereka juga merupakan penyambung lidah dari tokoh-tokoh tua (masyarakat). Dari 
itu, sebelum melakukan perkenalan kepada masyarakat umum, tim melakukan perkenalan sekaligus observasi kepada rekan-rekan pemuda di setiap dusun yang ada di Desa Buluagung. Banyak informasi yang kami dapatkan dari mereka terutama tentang permasalahan mereka dan masyarakat setempat.

5. Masyarakat

Setelah melakukan perkenalan dengan beberapa tokoh di Desa Buluagung, selanjutnya tim pengabdian memperkenalkan diri baik secara formal dan non formal dengan masyarakat. Selain itu, perkenalan juga kami lakukan dengan duduk santai dengan masyarakat setempat selain itu dilaksanakan juga bersih-bersih lingkungan pada setiap seminggu sekali. Usaha ini dilakukan dengan tujuan untuk menjalin komunikasi yang baik dengan masyarakat setempat, sehingga akan mempermudah dalam sosialisasi program tersebut.

\section{Hasil Dan Diskusi}

Pemberdayaan ini diawali dengan kegiatan bersih-bersih yang dilaksanakan untuk memicu kesadaran masyarakat untuk mengumpulkan sampah plastik di lokasi kegitan sebagai proses pembiasaaan hidup yang bersih dan peduli lingkungan sekaligus sebagai percontohan yang kami harapakan terbentuklah tradisi shodaqoh sampah plastik di Desa Buluagung.

Selanjutnya sosialisasi yakni pemberdayaan shodaqoh sampah plastik di balai Desa Buluagung kepada kepala dusun, pokja, ketua RT dan RW serta perangkat Desa Buluagung sekalian. Demi terselenggaranya program kami dengan visi menciptakan lingkungan bebas sanpah plastik. Sehingga Desa Buluagung menjadi desa inovasi yang memiliki icon aset wisata dengan lingkungan bersih yang bebas sampah plastik sesuai visi bapak Abdullah Azwar Anas, M.Si selaku bupati Banyuwangi. 


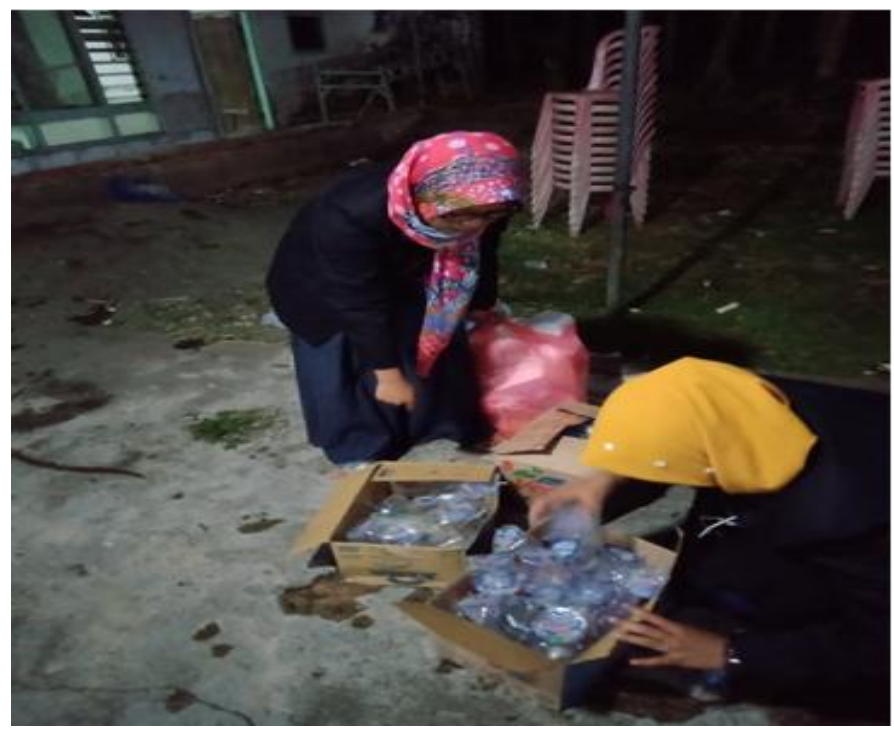

\section{Gambar 2. Mengumpulkan Sampah Plastik}

(Sumber: Kegiatan Lapangan, 2019)

Pada minggu ketiga, kepala dusun, ketua RT dan RW, pokja serta anggota BUMDES membagikan bank sampah 10 titik di setiap RT. Masyarakat antusias dengan penggalangan shodaqoh sampah plastik ini. Rencana ke depannya ketika kapasitas mesin membutuhkan lebih dari $10 \mathrm{~kg}$ setiap pengolahannya, dari pihak desa siap memeblikan yang lebih banyak kapasitasnya demi kebersihan desa dari sampah plastik serta. Dengan bertambahnya kapasitas maka bertambah pula hasil BBM yang terolah. Dengan begitu program ini insyaallah mampu membawa Desa Buluagung yang bersih, inovatif serta menjadi desa yang mandiri dengan pemasukan yang lumayan buah hasil shodaqoh sampah plastik.

Dengan terealisasinya shodaqoh sampah plastik dipasok ke lokasi pengolahan tepatnya di Dusun Krajan, tim sudah dapat merasakan dan membayangkan acuan program ini kedepannya terus terlaksana dan membuahkan hasil yang mensejahterakan masyarakat, lingkungan dan Desa Buluagung. Semoga dengan program ini dapat membantu Desa Buluagung terus berinovasi dan tetap menjadi desa percontohan di Banyuwangi. 


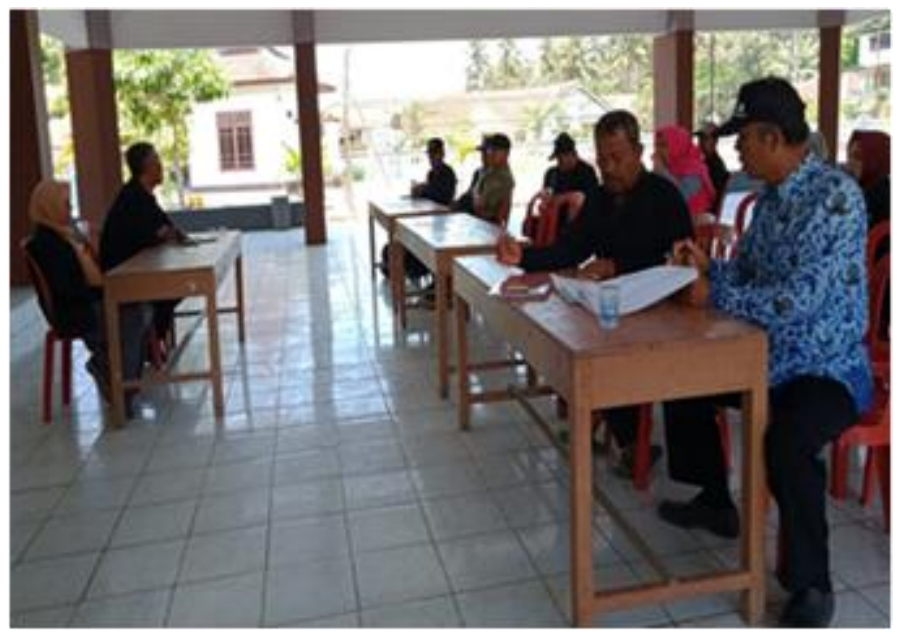

\section{Gambar 3. Koordinasi Dengan Masyarakat dan Perangkat Desa} (Sumber: Kegiatan Lapangan, 2019)

Kegiatan melaksanakan pemberdayaan shodaqoh sampah plastik, beberapa kepala dusun dan instansi desa beranggapan program ini sangat bagus dan efektif, juga dengan kehadiran tim dianggap mampu mengompakkan seluruh instansi karena tim berpijak di lintas pendidikan sehingga seluruh instansi atau kelompok berkenan menjalankan program yang diajukan. Dalam setiap rangkaian kegiatan tim selalu membiasakan untuk mesosialisasikan kebersihan dengan mengumpulkan sampah plastik yang ada di lokasi kegiatan demi terbentuknya tradisi peduli sampah plastik di Desa Buluagung.

Pengolahan sampah plastik waktu berlangsungnya sama di semua kapasitas baik kapasitas $10 \mathrm{~kg}$ sampai 1 kwintal. Dalam pengolahan dengan kapasitas $10 \mathrm{~kg}$, mengahsilkan BBM 7 liter dengan perincian 4 liter solar dan 3 liter bensin atau 3,5 liter solar dan 3,5 liter bensin. Sampah plastik, juga terdapat jenis dan kualitas yang berbeda-beda. Kualitas tertinggi dalam pengolahan, plastik bahan sterofom adalah kualitas tertinggi atau menghasilkan BBM terbanyak, urutah setelahnya adalah plastik biasa dan yang terakhir adalah plastik yang mengandung perak seperti bungkus kopi. 


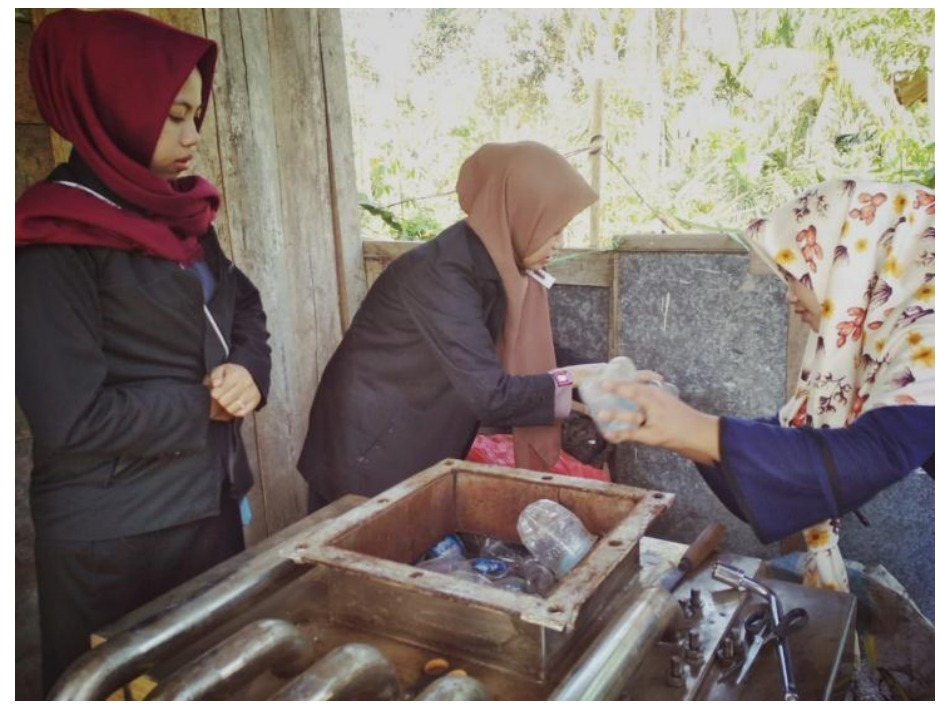

Gambar 4. Pengolahan Sampah Plastik

(Sumber: Kegiatan Lapangan, 2019)

Peningkatkan kualitas BBM khusus bensin, premium bias menjadi pertalite dengan mencampur satu tutup botol oktan, dengan 2 tutup oktan menjdi pertamax dan begitu selanjutnya. Program ini kami siapkan sedari awal karena tim yakin akan membantu sekali kedepannya untuk Desa Buluagung. Bentuk terimakasih kami menerima kami dengan suka hati dan segala penerimaan yang baik dan antusias, kami mampu menjalankan program ini dengan sebaiuk-baiknya.

Selama pelaksanaan program pengabdian sampai dengan sosialisasi Pemberdayaan Mayarakat Melalui Pengolahan Sampah Plastik Menjadi Premium dan Solar Alternatif di Desa Buluagung Kecamatan Siliragung Kabupaten Banyuwangi berjalan lancar bahkan mendapat respon baik dari masyarakat pada umumnya dan perangkat desa pada khususnya. Bahkan dari pihak desa sangat mendukung program kami dengan cara menginstruksi ke bagian kepala Rumah Tangga, kemudian Kepala rumah tangga mensosialisasikan kepada setiap Kepala Keluarga untuk memulai memperhatikan sampah yang dihasilkan. 
Selanjutnya dari pihak desa menyediakan bak penampung sampah pada 10 titik setiap dusunnya, dimana di setiap dusun tersebut diikuti oleh 7 Kepala Keluarga. Kemudian dari program yang telah ditetapkan oleh perangkat desa, masyarakat mulai dapat memilih dan memilah sampah yang dapat dijadikan untuk BBM.

Kendala pelaksanaan program adalah kurang adanya koordinasi antar sesama keaggotaan BUMDES Panji Samudra dengan masyarakat secara luas, sehingga dibutuhkan koneksitas yang positif untuk menggerakkan masyarakat dalam mensodaqohkannya sampah plastik.

Solusi selama pelaksanaan program Pertemuan dan komunikasi yang membangun antara tim pengabdian IAI Darussalam dengan Kepala desa didukung dengan perangkat desa dalam membahas tentang susunan keanggotaan BUMDES 'Panji Samudera' dan program kerja dari BUMDes tersebut supaya kineranya dapat ditingkan dalam memaksimalkan penggunaan mesin pengolah sampah plastik menjadi BBM tersebut dapat dimaksimalkan.

\section{Simpulan}

1. Perlunya pengoptimalan peran serta masyarakat dalam memanfaatkan alat pengolahan sampah plastik menjadi Bahan Bakar Minyak (BBM) di Desa Buluagung supaya dengan memanfaatkan sampah plastik tersebut selain dapat mengurangi sampah plastik namun juga dapat mendatangkan sumber pendapatan bagi masyarakat sekitarnya.

2. Perlunya penyegaran pada struktur organisasi BUMDES 'Panji Samudera', karena kurang koordinasi dan sinkronisasi komunikasi dengan masyarakat sehingga menyebabkan kurang maksimalnya pemanfaatan mesin katalisator plastik yang sudah ada. 


\section{Rekomendasi}

1. Warga masyarakat

Harus dapat menumbuhkan jiwa kepercayaan serta kepemilikan terhadap asset yang dimiliki oleh desa dengan mulai memikirkan serta membantu perangkat desa dalam menjalankan aset desa seperti mesin katalisatior plastik yang dikelola oleh BUMDes 'Panji Samudera'.

2. Keanggotaan BUMDes 'Panji Samudera'

Pengelola BUMDes harus dapat membangun koordinasi yang baik antar sesama anggota untuk dapat meningkatkan kegiatan BUMDes tersebut

3. Pemerintah Desa Buluagung

Pemerintah Desa Buluagung supaya terus meningkatkan kinerja dalam mengoptimalkan asset yang ada di Desa Buluagung diantaranya dengan mengadakan pelatihan ataupun sosialisasi tentang pemanfaatan aset desa yang sudah ada.

\section{Daftar Referensi}

BPS Kabupaten Banyuwangi. Kecamatan Siliragung dalam Angka Tahun 2018., BPS: Banyuwangi, 2019.

Desa Buluagung. Profil Desa Buluagung Tahun 2018. Desa Buluagung, 2019.

Tim penyusun. Pedoman Kuliah Kerja Nyata Participatory Action Research Tahun 2019 IAI Darussalam Blokagung. LPPM: Banyuwangi, 2019. 